CATALLAXY

Volume 2 Issue 2 December 2017

e-ISSN 2544-090X

¿ www.catallaxy.pl

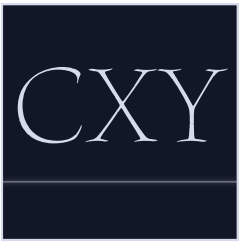

Oryginalny artykut naukowy

otrzymano: 25.10.2017 / zaakceptowano: 01.12.2017 / opublikowano online: 31.12.2017

Pogorzelski, A. (2017). Bezpieczeństwo energetyczne Polski w latach 2010-2015: aspekty ekonomiczne. Catallaxy, 2(2): 59-70. doi:10.24136/cxyv2i2.1.

\title{
Bezpieczeństwo energetyczne Polski w latach 2010-2015: aspekty ekonomiczne
}

\author{
ADAM POGORZELSKI \\ Uniwersytet Mikołaja Kopernika w Toruniu, Wydział Nauk Ekonomicznych i Zarzadzania, ul. Gagarina 13a, \\ 87-100 Torun, Polska \\ వadampogorzelski310@gmail.com \\ (D) orcid.org/0000-0002-3285-8402
}

\begin{abstract}
Abstrakt
Motywacja: Kwestia energetyki jest zagadnieniem, które systematycznie powraca do debaty politycznej. Obecnie w opinii publicznej brakuje konsensusu dotyczącego optymalnej struktury pozyskiwania energii, która miałaby zapewnić Polsce bezpieczeństwo energetyczne. Chęć ukazania związku między biezącą sytuacją polskiej energetyki a bezpieczeństwem energetycznym Polski, była głównym motywem wyboru tematu niniejszego artykułu.

Cel: Celem artykułu jest ukazanie związku między wykorzystaniem konwencjonalnych i odnawialnych źródeł energii a bezpieczeństwem energetycznym Polski w kontekście aspektów ekonomicznych.

Wyniki: Na podstawie przeprowadzonej analizy wykazano zbyt niski poziom dywersyfikacji źródeł energii, nadmierną zależność importową od Rosji, znaczną energochłonność gospodarki oraz bezzasadne, nadmierne wsparcie dla branży górniczej. Na podstawie przeprowadzonej analizy można jednak zaobserwować też stopniową poprawę sytuacji Polski w przytoczonych kwestiach.
\end{abstract}

Stowa kluczowe: bezpieczeństwo energetyczne; konwencjonalne źródła energii; odnawialne źródta energii; energetyka JEL: Q40; Q42; Q43; Q48

\section{Wprowadzenie}

Jednym $z$ głównych stymulatorów rozwoju współczesnej gospodarki jest energia elektryczna. Jest ona nietypowym dobrem, ponieważ nie posiada substytutów, a z jej wytwarzaniem wiąże się powstawanie znacznych ilości zanieczyszczeń, które negatywnie wpływają na środowisko. Do zadań rządów państw Unii Europejskiej (UE) należy zapewnienie bezpieczeństwa energetycznego, które należy rozpatrywać także w ujęciu ekonomicznym.
Państwa członkowskie UE coraz częściej korzystają ze źródeł energii odnawialnej (OZE). Wśród nich znajduje się Polska, która jest państwem posiadającym relatywnie niski udział OZE w całkowitym pozyskaniu energii elektrycznej, jednak stopniowo jest on zwiększany. Powstaje pytanie, jak struktura źródeł energii wpływa na bezpieczeństwo energetyczne, skoro źródła konwencjonalne stopniowo się wyczerpują, a OZE mogą nie być wystarczające do zaspokojenia popytu na energię. 
Celem artykułu jest ukazanie związku między wykorzystaniem konwencjonalnych i odnawialnych źródeł energii a bezpieczeństwem energetycznym Polski w kontekście aspektów ekonomicznych.

W niniejszym artykule dokonano syntezy aktualnego stanu wiedzy o polskiej energetyce. Przeprowadzono analizę jej mocnych i słabych stron w kontekście aspektów ekonomicznych oraz przedstawiono potencjalne korzyści dla Polski wynikające ze zmiany struktury źródeł pozyskiwanej energii.

Zakres czasowy niniejszego artykułu stanowią lata 2010-2015 ze względu na ograniczoną dostępność danych z lat 2016-2017.

W Sekcji 2. dokonano przeglądu literatury. W Sekcji 3. przedstawiono wykorzystane metody badawcze. W Sekcji 4. dokonano analizy aspektów ekonomicznych bezpieczeństwa energetycznego Polski $\mathrm{w}$ analizowanym okresie. W Sekcji 5. zaprezentowano wnioski z przeprowadzonej analizy.

\section{Przegląd literatury}

Kwestie bezpieczeństwa energetycznego oraz źródeł energii są istotnymi oraz często wspominanymi tematami $\mathrm{w}$ debacie politycznej. $Z$ tego powodu powstało wiele publikacji i raportów dotyczących tej problematyki.

K.M. Pronińska (2013), przedstawiła korzyści finansowe związane $z$ zastosowaniem OZE. Jej argumentacja wykorzystano w celu ukazania pozytywnych aspektów związanych $z$ inwestowaniem $w$ źródła niekonwencjonalne oraz podkreślenia zasadności tych inwestycji.

K. Baca-Pogorzelska (2016), opisała sytuację polskiego górnictwa. Analizę tę użyto w celu wyjaśnienia wysokich cen polskiego węgla oraz niskiej efektywności całej branży, co skutkowało importem surowca z zagranicy.

Agencja IEA (2017), dokonała szczegółowej analizy polskiej energetyki oraz jej mocnych i słabych stron. Na podstawie przytoczonego raportu dokonano oceny stopnia uzależnienia Polski od dostawców ropy naftowej i gazu ziemnego, a także wpływu budowy terminalu LNG (liquefied natural gas) na poprawę bezpieczeństwa energetycznego Polski.

GUS (2011b-2016b), przedstawil dane dotyczące wielkości wydobycia i konsumpcji źródeł energii oraz ich eksportu i importu. Informacje te wykorzystano w celu zobrazowania sytuacji polskiej energetyki.

W raportach European Commission (2016), przedstawiono dane dotyczące energetyki państw członkowskich UE. Na ich podstawie dokonano oceny stopnia uzależnienia energetycznego Polski na tle innych państw.

W raporcie WiseEuropa (2017), dokonano analizy kosztów związanych ze wsparciem dla górnictwa w Polsce. Raport wykorzystano w celu zobrazowania realnych kosztów związanych $z$ polską energetyką opartą na węglu w porównaniu do kosztów związanych z wykorzystaniem OZE.

W przytoczonych publikacjach rozpatrywano kwestię bezpieczeństwa energetycznego Polski $z$ różnych stron i w odmiennym zakresie czasowym. Brak syntetycznego opisu wszystkich, omówionych kwestii w latach 2010-2015 stanowi lukę poznawczą. W niniejszym artykule dokonano syntezy wiedzy dotyczącej aspektów ekonomicznych bezpieczeństwa energetycznego Polski.

\section{Metody}

W niniejszym artykule wykorzystano kilka metod badawczych. W części teoretycznej posłużono się analizą opisową i porównawczą. W części empirycznej wykorzystano analizę wskaźnikową do zobrazowania ekonomicznych problemów polskiej energetyki. Posłużono się w niej wskaźnikiem zależności importowej oraz wskaźnikiem intensywności energetycznej.

\section{Wyniki badania}

\subsection{Bilans energetyczny Polski w latach 2010-2015}

Polska energetyka $\mathrm{w}$ analizowanym okresie oparta była na węglu. Całkowita, roczna kon- 
sumpcja energii w latach 2010-2015 oscylowała w graniach 100 Mtoe1. Na wykresie 1. przedstawiono strukturę konsumpcji energii w Polsce ze względu na nośniki w 2015 r. $\mathrm{Na}$ podstawie informacji na nim zawartych można stwierdzić, że łączny udział węgla w konsumpcji energii wynosił około $51 \%$. Pozostałymi, największymi nośnikami energii w Polsce były: ropa naftowa (26\%) i gaz ziemny (14\%) (GUS, 2012b-2016b).

W inny sposób kształtowała się struktura pozyskiwanej energii, której całkowita wielkość wynosiła w latach 2010-2015 około 70 Mtoe. Na wykresie 2. przedstawiono strukturę pozyskania energii w Polsce w 2015 r. $\mathrm{Na}$ podstawie informacji na nim zawartych można zauważyć, że łączny udział węgla w konsumpcji energii stanowił około $79 \%$, zaś ropy naftowej i gazu ziemnego odpowiednio: $1 \%$ i $5 \%$. Pozostałe $15 \%$ udziału w pozyskaniu stanowiły inne nośniki energii, wśród których znajdowały się także OZE, których wkład był równy około 13\% (GUS, 2012b-2016b; 2015a-2016a).

Wydobycie węgla w latach 2010-2013 wynosiło około 44 Mtoe, zaś w latach 20142015 - 42 Mtoe. Zużycie tego surowca malało do 2015 r. z 48 Mtoe do około 41 Mtoe, natomiast w 2016 r. zauważalnie wzrosło. Wysokie zapotrzebowanie na węgiel na początku analizowanego okresu, skutkowało importem surowca $z$ zagranicy (GUS, 2012b-2016b; 2017, ss. 22-23).

Polska $\mathrm{w}$ analizowanym okresie była importerem netto ropy i gazu ziemnego. Wydobycie ropy $w$ Polsce $w$ latach 2010-2015 nie przekraczało 1 Mtoe, zaś jej zużycie sięgało około 25 Mtoe. W przypadku gazu ziemnego sytuacja kształtowała się bardziej korzystnie. Roczne wydobycie w latach 2010-2015 stanowiło około 3,9 Mtoe, zaś konsumpcja stanowiła jedynie około 15 Mtoe (GUS, 2012b-2016b). Większość importu tych surowców pochodziła od jednego dostawcy. Według danych IEA (2017, s. 158), zaczerpniętych $z$ Ministerstwa Energii, w 2015 r. import ropy naftowej z Rosji stanowił ponad $88 \%$ całkowitego importu tego surowca. Na- tomiast, zgodnie z danymi IEA (2017, s. 140), największymi dostawcami gazu ziemnego do Polski w 2015 r. były Rosja i Niemcy. Udział dostaw gazu z tych państw w całkowitym, polskim imporcie „błękitnego paliwa” był równy odpowiednio $72 \%$ i $26 \%$.

Udział OZE w polskiej energetyce zwiększał się wolniej, niż w państwach UE-28 (wykres 3.). Wzrost ten $\mathrm{w}$ analizowanym okresie zdeterminowany był głównie intensywnym rozwojem energetyki wiatrowej (GUS, 2015a-2016a).

Do trzech najważniejszych źródeł niekonwencjonalnych $\mathrm{w}$ Polsce w 2015 r. należały: biopaliwa stałe, biopaliwa ciekłe i energia wiatru. Ich udział $w$ pozyskaniu energii $z$ OZE stanowił kolejno: $72,22 \%, 10,78 \%$ i 10,76\%. Pozostałe, alternatywne źródła energii były wykorzystywane w nieznacznym stopniu (GUS, 2016a).

Problemem polskiej energetyki $w$ analizowanym okresie był brak możliwości osiągnięcia średniego poziomu UE-28 w wykorzystaniu OZE, który w latach 2010-2014 wzrósł z $20,1 \%$ do $25,2 \%$. Mimo stopniowego wzrostu udziału OZE w gospodarce $z$ 10,2\% do 12,7\% w latach 2010-2015 r., dystans między Polską a UE-28 powiększał się. Odpowiednie zbilansowanie poziomu pozyskania energii z OZE i źródeł konwencjonalnych jest jednym $z$ warunków osiągnięcia bezpieczeństwa energetycznego.

$\mathrm{Na}$ wykresie 4. przedstawiono przyrost mocy osiągalnych rok do roku elektrowni ogółem wykorzystujących energię z OZE w Polsce w latach 2010-2017 według stanu na 30.06.2017 r. Można zaobserwować wahania tempa rozwoju energetyki $\mathrm{w}$ analizowanym okresie, jednak w 2017 r. nastąpił znaczący spadek przyrostu mocy zainstalowanej w elektrowniach OZE. Należy wspomnieć, że największy udział w przyroście mocy zainstalowanej $\mathrm{w}$ analizowanych latach stanowity elektrownie wiatrowe (URE, 2017). Tak nagły spadek można wytłumaczyć zmianami legislacyjnymi ograniczającymi rozwój energetyki wiatrowej. 


\subsection{Ekonomiczne aspekty wytwarzania energii w Polsce}

Polskę, w analizowanym okresie, cechował wysoki poziom zaspokojenia popytu na energię pierwotną za pomocą krajowego wydobycia surowców. Wynikało to ze znacznych zasobów węgla na terenie państwa oraz od oparcia na nim polskiej energetyki. Mimo wysokiego wydobycia tego surowca, według danych GUS (2012b-2016b), Polska w latach: 2010-2012 oraz 2014 r. była importerem netto tego nośnika energii. Przyczyną tego były względnie wysokie ceny węgla wydobywanego na terenie państwa, w porównaniu do cen zagranicznych tego surowca. Wysokie ceny węgla podyktowane były wieloma czynnikami. Do najwazniejszych można zaliczyć (Baca-Pogorzelska, 2016):

- przestarzałą technologię i brak wystarczających inwestycji w tym kierunku;

- wysoki udział kosztów stałych, który przekraczał $80 \%$ całkowitych kosztów;

- niską wydajność pracy robotników;

- złą organizację pracy (maszyny nie były w maksymalny sposób wykorzystywane).

Do powyższych czynników należy dodać również stopniowe wyczerpywanie się łatwiej dostępnych pokładów surowca. Dalsza jego eksploatacja wymaga wydobycia na wiele większej głębokości, co skutkuje wzrostem kosztów i spadkiem efektywności. Jak podaje WiseEuropa (2015, s. 23), na podstawie danych Eurostat, DECC (Department of Energy $\mathcal{E}$ Climate Change) oraz EIA (U.S. Energy Information Administration), produktywność polskich kopalń w 2012 r. wyniosła około 700 t na jednego pracownika. Dla porównania, wydobycie przypadające na jednego górnika w USA w 2012 r. wynosiło około 4500 t.

Wysokie koszty stałe były przyczyną, dla której wstrzymanie produkcji było nieopłacalne, ponieważ nie są one zależne od ilości wytwarzanych dóbr przez dane przedsiębiorstwo. Wraz ze wzrostem produkcji następuje spadek jednostkowych kosztów stałych przekładających się na cenę produktu. $Z$ kolei tendencja spadkowa konsumpcji węgla skutkowała zmniejszeniem wydobycia, co w efek- cie powodowało wzrost jednostkowej ceny za tonę tego surowca. Polskie górnictwo, przy rosnących cenach, nie było w stanie efektywnie konkurować z zagranicznymi przedsiębiorstwami $z$ branży górniczej. W celu wsparcia rodzimego górnictwa, rząd finansował dopłaty do przynoszącej straty branży.

W kontekście dopłat do górnictwa należy nadmienić, że wielkość wsparcia dla polskich kopalń i elektroenergetyki węglowej w latach 2010-2016 była równa 64 mld PLN, zaśłączne wsparcie dla OZE w tym okresie wyniosło jedynie 25 mld PLN. Szacuje się, że wsparcie dla górnictwa i elektroenergetyki węglowej w latach 2017-2030 wyniesie 154,8 mld PLN. W samym 2016 r. koszt wsparcia tych branż na jednego obywatela był równy 239 PLN. Po doliczeniu kosztów zewnętrznych, wyniósł on 1045 PLN. Dla porównania, łączny koszt wsparcia OZE w 2016 r. przypadający na jedną osobę wyniósł 42 PLN (WiseEuropa, 2017, ss. 31-37).

Bezpieczeństwo energetyczne Polski może być oceniane na podstawie wskaźnika zależności importowej $\left(W_{i}\right)$ obliczanego według wzoru (1):

$$
W_{i}=\left[\left(I_{i}-E_{i}\right) / Z_{i}\right] \cdot 100 \%,
$$

gdzie:

$I_{i}$ - import $i$-tego surowca;

$E_{i}$ - eksport $i$-tego surowca;

$Z_{i}$ - zużycie krajowe $i$-tego surowca.

Na podstawie poziomu wskaźnika można wyciągnąć wniosek, że Polska w 2015 r. była jednym $z$ najbardziej niezależnych państw UE pod względem importowanych surowców energetycznych. Obliczony poziom wskaźnika dla Polski w latach 2010-2015 przedstawiono na wykresie 5. Oscylowat on $w$ okolicach $30,0 \%$ przy $53,5 \%$ dla UE-28 w 2014 r. (European Commission, 2016, ss. 175-217). Należy jednak zauważyć, że mimo wysokiego poziomu wykorzystania rodzimego węgla w gospodarce, w Polsce udokumentowane pokłady gazu ziemnego oraz ropy naftowej były nieznaczne, natomiast ich konsumpcja wysoka. W przypadku gazu ziemnego w Polsce, $\mathrm{w}$ analizowanym okresie, zaspokajano około 
$25 \%$ popytu rodzimym paliwem, natomiast wydobycie ropy było znacznie mniejsze.

Warto zauważyć, że w przypadku gazu ziemnego, tempo jego wydobycia było względnie niskie $\mathrm{w}$ Polsce, $\mathrm{w}$ porównaniu do państw o podobnych zasobach tego surowca. Przykładowo, wydobycie w Niemczech w 2016 r. stanowiło około $167 \%$ wydobycia polskiego przy zbliżonych zasobach, a w latach wcześniejszych różnica była jeszcze większa (BP, 2017). Należy jednak podkreślić, że zwiększenie tempa wydobycia „błękitnego paliwa” skutkowałoby zwiększeniem tempa wyczerpywania się zasobów, które były względnie niewielkie.

Ważną kwestią jest fakt, że samowystarczalność energetyczna nie jest warunkiem niezbędnym do osiągnięcia bezpieczeństwa energetycznego. Można je osiągnąć za pomocą odpowiedniej dywersyfikacji dostaw potrzebnych surowców, co minimalizuje ryzyko uzależnienia od dostawcy. W przypadku Polski, głównym dostawcą ropy i gazu w analizowanym okresie była Rosja. Należy więc odpowiedzieć na pytanie, na ile przewidywalnym i bezpiecznym dostawca, z punktu widzenia Polski, było to państwo. Warto zwrócić uwage na działania Rosji w przeszłości dotyczące dostaw gazu do państw europejskich. W 2006 i 2009 r. Rosja wstrzymała dostawy gazu ziemnego do Ukrainy, co spowodowało także spadek ciśnienia dostarczanego gazu do innych państw (Gawlik, 2009). Warto też wspomnieć, że gaz ziemny stanowił dla Rosji narzędzie polityczne. Ceny tego paliwa ustalane były w Rosji odgórnie dla poszczególnych państw. Niestabilność cen gazu i ropy naftowej może być przyczyną wzrostu inflacji oraz zmniejszenia popytu wewnętrznego $\mathrm{w}$ gospodarce, co może skutkować spadkiem wzrostu gospodarczego (Księżopolski, 2013, s. 17).

Należy także przytoczyć plany budowy gazociągu Nord Stream 2. Projekt ten zakłada budowę gazociągu między Rosją a Niemcami przez Morze Bałtyckie z pominięciem państw tranzytowych. Projekt ten, mimo zapewnień o jego biznesowym charakterze, wywołał wiele kontrowersji. Spowodowane one były wcześniejszymi, sankcjami nałożonymi na Rosje oraz niezgodnością samego projektu z prawem unijnym, według którego jedno przedsiębiorstwo nie może być odpowiedzialne jednocześnie za przesył i wydobycie surowca. Projekt stanowił potencjalnie istotne zagrożenie dla bezpieczeństwa energetycznego Polski ze względu na utracone przychody $z$ tytułu bycia państwem tranzytowym oraz $z$ powodu potencjalnej likwidacji Jamału - gazociągu przechodzącego przez polskie terytorium. W takiej sytuacji zagrożone byłyby dostawy błękitnego paliwa do Polski (Słomski, 2017).

Na podstawie tych informacji można wyciągnąć wniosek, że stopień zróżnicowania źródeł dostaw ropy i gazu w Polsce był niekorzystny i wymagał znalezienia innych dostawców lub dywersyfikacji poprzez większe wykorzystanie innych źródeł energii.

Przykładem działań mających na celu zwiększenie stopnia dywersyfikacji dostaw gazu w Polsce była budowa terminalu LNG w Świnoujściu, która była realizowana w analizowanych latach. Jego instalacja miała na celu umożliwienie dostarczania skroplonego gazu ziemnego $\mathrm{w}$ postaci ciekłej drogą morską $z$ dowolnego miejsca na świecie, a następnie ponowną regazyfikację tego paliwa. Roczną zdolność do odbioru gazu ziemnego oszacowano na $5,0 \mathrm{mld} \mathrm{m}^{3}$, co stanowi ponad $25 \%$ rocznej, polskiej konsumpcji tego surowca. Ponadto oszacowano, że możliwe jest zwiększenie możliwości regazyfikacyjnej do $7,5 \mathrm{mld}^{3}$. Największymi zaletami tej inwestycji są:

- elastyczność dostaw, która umożliwia nie tylko zwiększenie dywersyfikacji źródeł dystrybucji, lecz także zaspokojenie szczytowego zapotrzebowania na to paliwo;

- niskie koszty, ponieważ magazynowanie i transport skroplonego gazu ziemnego jest bardziej ekonomiczne;

- ponad sześćset razy mniejsza objętość LNG od gazu.

W grudniu 2015 r. w Świnoujściu odebrano pierwszy ładunek pochodzący z Kataru. Budowa terminalu $\mathrm{w}$ istotny sposób zwiększyła bezpieczeństwo energetyczne Polski (Gaz-system, 2017; IEA, 2017, ss. 140-154; Polskie LNG, 2017).

Kolejnym, pozytywnym działaniem umożliwiającym zapewnienie ciągłości dostaw, 
było rozpoczęcie budowy terminalu naftowego w Gdańsku w 2013 r., którego pojemność wynosiła 375 tys. $\mathrm{m}^{3}$, a także rozpoczęcie długoterminowego projektu Baltic Pipe. Budowa terminalu miała umożliwić zakup większych ilości ropy po korzystniejszych cenach, a także magazynowanie tego paliwa i jego sprzedaż $z$ zyskiem (Money, 2016). Natomiast projekt Baltic Pipe został rozpoczęty w celu budowy gazociągu łączącego Polskę i Danię, który miał umożliwić dostęp państwom skandynawskim do globalnego rynku tego surowca, a także poprawę jakości dostaw (Gaz-system, 2017; IEA, 2017, s. 141). Na podstawie przytoczonych informacji można wyciągnąć wniosek, że $\mathrm{w}$ analizowanym okresie $\mathrm{w}$ Polsce istniała świadomość zagrożeń wynikających $z$ braku dostatecznej dywersyfikacji paliw i zbyt dużego uzależnienia od Rosji. Rząd, a także prywatne przedsiębiorstwa, wdrażały inwestycje, które miały skutkować zwiększeniem bezpieczeństwa energetycznego.

Dobrym sposobem dywersyfikacji źródeł konsumowanej energii jest zwiększanie udziału OZE w całkowitym wykorzystaniu energii. Dzięki temu, udział konwencjonalnych źródeł sukcesywnie maleje, co przekłada się na zmniejszanie znaczenia paliw importowanych.

OZE wykorzystywane są jedynie ze źródeł dostępnych na terytorium danego państwa, które ponadto są niewyczerpywalne, albo łatwo odnawialne, co pozwala na osiągnięcie samodzielności energetycznej. W przypadku czystych OZE (Słońce, wiatr, woda, energia geotermalna), jedynym kosztem, który jest ponoszony, to koszt budowy elektrowni bazującej na OZE. Źródło energii jest darmowe. Ponadto, ogólne trendy i prognozy sugerowały stopniowy spadek cen instalacji i technologii, co przekłada się na niższe ceny energii (Pronińska, 2013, s. 48).

Należy zauważyć, że wzrost znaczenia OZE w gospodarce skutkuje większą niezależnością od wahań cen ropy i gazu, które są niekorzystne dla gospodarki. Co więcej, ceny OZE nie podlegają wahaniom na rynku światowym (Księżopolski, 2013, ss. 17-27). Ponadto, zważywszy na wyczerpywalność źródeł konwencjonalnych, można założyć, że w przyszłości ich cena może znacznie wzrosnąć, co mogłoby spowolnić rozwój gospodarczy i utrudnić inwestycje w alternatywne źródła pozyskiwania energii. $Z$ tego powodu stopniowe inwestycje w OZE są istotne dla bezpieczeństwa energetycznego.

Według danych GUS (2015a-2016a), wielkość udziału energii z OZE w pozyskaniu w Polsce była znacznie mniejsza od średniej państw UE. Zdecydowana większość pozyskiwanej energii pochodziła $z$ biomasy, co wyróżniało Polskę na tle pozostałych państw. Pozyskanie energii $z$ pozostałych OZE było jednak na niskim poziomie. Energia słońca i wód podziemnych była wykorzystywana w śladowych ilościach. Pozyskanie energii $z$ wód powierzchniowych malało $w$ analizowanym okresie. Brak odpowiedniego zagospodarowania dostępnych źródeł, można porównać do ich marnotrawstwa. Jedynym, prężnie rozwijanym, czystym OZE w Polsce $\mathrm{w}$ analizowanym okresie była energia wiatru.

OZE stanowią dobre uzupełnienie źródeł konwencjonalnych. Za ich pomocą można zniwelować wiele wad klasycznych źródeł energii takich, jak: wahania cen, problem dostępności itp. Ponadto można stwierdzić, że stanowią one przyszłość energetyki. Złoża konwencjonalne są wyczerpywalne, zatem sposobu na zaspokojenie popytu na energię najprawdopodobniej będzie się szukać w OZE. Świadomość istnienia tych trendów daje możliwość odpowiedniego reagowania na pojawiające się problemy. Polski rozwój OZE był raczej wypadkową nałożonych ograniczeń oraz celów unijnych, niż świadomym dążeniem do zapewnienia bezpieczeństwa energetycznego.

Mimo wielu zalet, OZE obarczone są również wadami. Najważniejszą z nich jest relatywnie wysoka cena energii $w$ porównaniu do źródeł tradycyjnych. W analizowanym okresie, ceny energii z OZE były wyższe i wymagały rządowego wsparcia. Ponadto, elektrownie nie zawsze są w stanie sprostać zapotrzebowaniu na energię. Należy mieć jednak na uwadze, że $w$ związku z postępem technicznym, ceny energii z OZE w przyszłości mogą zrównać się $z$ cenami energii ze źródeł konwencjonalnych. 
Kolejnym, ważnym aspektem ekonomicznym jest wskaźnik intensywności energetycznej państwa $\left(E I_{t}\right)$, obliczony według wzoru (2):

$$
E I_{t}=K_{t} / P K B_{t},
$$

gdzie:

$K_{t}$ - całkowita konsumpcja energii w danym państwie w okresie t;

$P K B_{t}-\mathrm{PKB}$ danego państwa w okresie $t$.

Wskaźnik ten dostarcza informacji o stopniu energochłonności gospodarki. Im bardziej innowacyjna jest gospodarka, tym wyższa jest jej efektywność wykorzystania energii. Zmniejszenie energochłonności pozwala na mniejsze uzależnienie od importowanych źródeł energii. Oznacza to, że im mniejszy poziom wskaźnika, tym korzystniejsza jest sytuacja analizowanej gospodarki.

$\mathrm{Na}$ wykresie 6. przedstawiono porównanie energochłonności polskiej gospodarki z UE-28. Według danych Eurostat (2017), poziom intensywności energetycznej Polski w latach 2010-2015 malał z poziomu 278,3 do 227,3 , natomiast średni poziom wskaźnika dla UE-28 w analizowanym okresie była redukowana $z$ poziomu 137,5 do 120,0 . Oznacza to, że polska gospodarka, pod względem energochłonności, wymagała w analizowanym okresie znacznych inwestycji, ponieważ istotnie różniła się $w$ tej kwestii od średniej unijnej. Energochłonność, na tak wysokim poziomie, powoduje zwiększone zapotrzebowanie energetyczne w gospodarce, co skutkuje wyższymi kosztami, ponoszonymi w celu zaspokojenia popytu na energię. Zarówno wysoka cena nośników energii, jak i ich zawyżona ilość, która jest potrzebna do wytworzenia jednostki dobra, może negatywnie wpływać na PKB danego państwa oraz na jego konkurencyjność.

\section{Zakończenie}

Przeprowadzona analiza aspektów ekonomicznych uprawnia do wyciągnięcia kilku wniosków. Po pierwsze, mimo niskiego wskaźnika zależności importowej, Polska była silnie uzależniona od dostaw gazu ziemnego oraz ropy naftowej z Rosji w analizowanym okresie.
Po drugie, można także zaobserwować działania mające na celu stopniowe zmniejszanie tej zależności poprzez budowę terminali LNG, czy też powolne zwiększanie poziomu dywersyfikacji paliw. Po trzecie, polska energetyka $\mathrm{w}$ analizowanym okresie była zdominowana przez węgiel, z którym wiązały się problemy wysokich cen polskiego surowca oraz nierentowności kopalń, dofinansowywanych $z$ budżetu państwa. Problem polskiego górnictwa na koniec analizowanego okresu, pozostał wciąż nierozwiązany. Po czwarte, istotnym, $z$ ekonomicznego punktu widzenia, był także wysoki poziom energochłonności polskiej gospodarki w porównaniu do średniej UE. Był on wywołany m.in. przestarzałą technologią. $\mathrm{Na}$ leży jednak zaznaczyć, że poziom wskaźnika energochłonności był stopniowo redukowany.

Podsumowując, należy zauważyć liczne, korzystne działania, których celem było zwiększenie bezpieczeństwa energetycznego Polski. Jednak należy także uwzględnić wciąż istniejący ogromny dystans w aspektach ekonomicznych między Europą Zachodnią a Polską.

Bibliografia

Baca-Pogorzelska, K. (2016). Górnictwo $w$ Polsce: szanse i zalety vs wady i ryzyka. Pobrane 16.05.2017 z https://www.obserwatorfinansowy.pl.

BP. (2017). Statistical review of world energy. Pobrane 28.09.2017 z http://www.bp.com.

European Commission. (2016). EU energy in figures. Statistical pocketbook 2016. Pobrane 21.10.2017 $z$ https://ec.europa.eu.

Eurostat. (2017). Pobrane 21.10.2017 z http:// ec.europa.eu.

Gawlik, P. (2009). Ukraińskie MSZ: Rosja może tak postąpićz każdym. Pobrane 15.05.2017 z http:// www.rp.pl.

Gaz-system. (2017). Pobrane 02.04.2017 z http:// www.gaz-system.pl.

GUS. (2015a-2016a). Energia ze źródet odnawialnych w latach 2014-2015. Pobrane 26.04.2017 $z$ http://stat.gov.pl.

GUS. (2011b-2016b). Gospodarka paliwowo-energetyczna w latach 2010-2015. Pobrane 01.04.2017 z http://stat.gov.pl. 
GUS. (2017). Energia 2017. Pobrane 21.10.2017 $z$ http://stat.gov.pl.

IEA. (2017). Energy policies of IEA countries. Poland. 2016 review. Pobrane 03.04.2017 z https:// www.iea.org.

Księżopolski, K.M. (2013). Wpływ odnawialnych źródeł energii na bezpieczeństwo ekonomiczne Polski. W: K.M. Księżopolski, K.M. Pronińska, i A.E. Sulowska (red.), Odnawialne źródła energii $w$ Polsce. Wybrane problemy bezpieczeństwa, polityki i administracji. Warszawa: Elipsa.

Money. (2016). Ruszyt strategiczny Terminal Naftowy PERN w Gdańsku. Pobrane 16.05.2017 z http:// www.money.pl.

Pogorzelski, A. (2017). Konwencjonalne i odnawialne źródta energii a bezpieczeństwo energetyczne Polski w latach 2010-2015. Nieopublikowana praca licencjacka. Uniwersytet Mikołaja Kopernika, Toruń.

Polskie LNG. (2017). Pobrane 23.05.2017 z http:// www.polskielng.pl.

Pronińska, K.M. (2013). Wpływ rozwoju odnawialnych źródeł energii na bezpieczeństwo energetyczne Polski. W: K.M. Księżopolski, K.M. Pronińska, i A.E. Sulowska (red.), Odnawialne źódta energii w Polsce. Wybrane problemy bezpieczeństwa, polityki $i$ administracji. Warszawa: Elipsa.
Słomski, D. (2017). Nord Stream II. Co oznacza dla Polski rozbudowa gazociagu? Pobrane 01.10.2017 z https://www.money.pl.

URE. (2017). Pobrane 12.10.2017 z https://www. ure.gov.pl.

WiseEuropa. (2015). Polski wegiel: Quo Vadis? Perspektywy rozwoju górnictwa wegla kamiennego $w$ Polsce. Pobrane 12.10.2017 z http://wise-europa.eu.

WiseEuropa. (2017). Ukryty rachunek za węgiel 2017 Wsparcie górnictwa i energetyki węglowej w Polsce - wczoraj, dziś i jutro. Pobrane 12.10.2017 $z$ http://wise-europa.eu.

\section{Informacje uzupetniające}

Wkład autorski: autor zaakceptował ostateczną wersję artykułu.

Źródła finansowania: artykuł został w całości sfinansowany ze środków własnych autora.

Uwagi: wyniki badania byly zaprezentowane $w$ innej formie, tj. pracy licencjackiej Pogorzelski (2017). 


\section{Aneks}

Wykres 1.

Struktura konsumpcji energii pierwotnej w Polsce w 2015 r. (w \%)

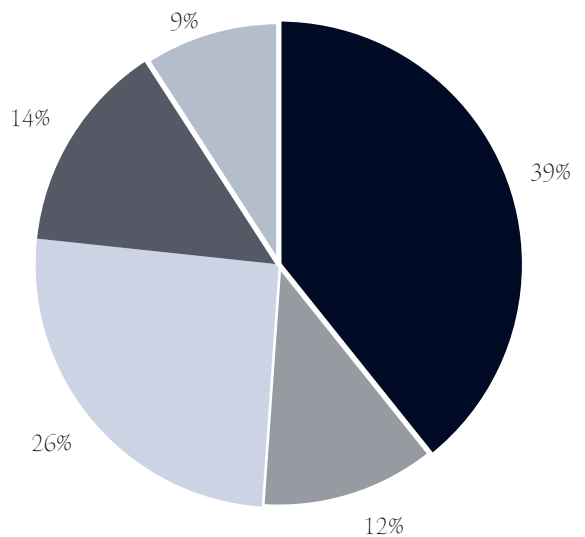

- węgiel kamienny

- węgiel brunatny

ropanaftowa

qaz ziemny

- inne

Źródło: Opracowanie własne na podstawie GUS (2016b).

Wykres 2.

Struktura pozyskania energii pierwotnej w Polsce w 2015 r. (w \%)

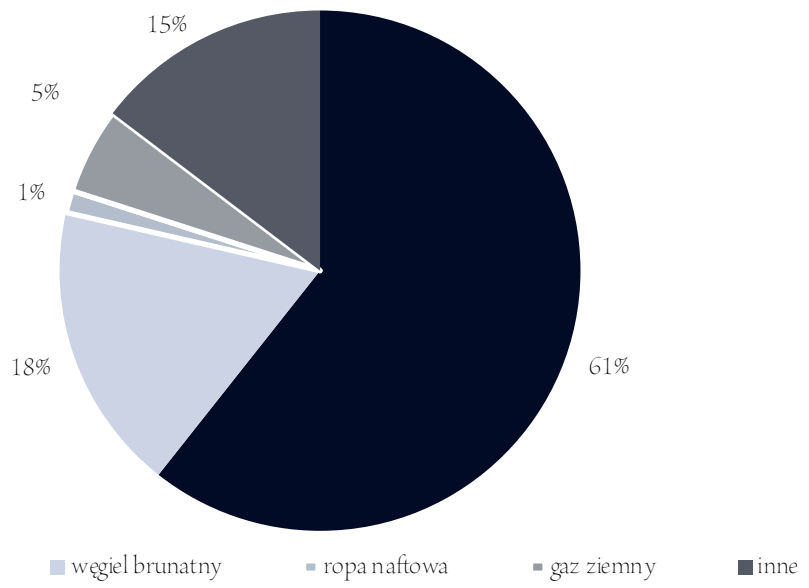

Źródło: Opracowanie własne na podstawie GUS (2016b). 
Wykres 3.

Udział OZE w pozyskaniu energii pierwotnej ogółem w Polsce i UE-28 w latach 2010-2015 (w \%) 29

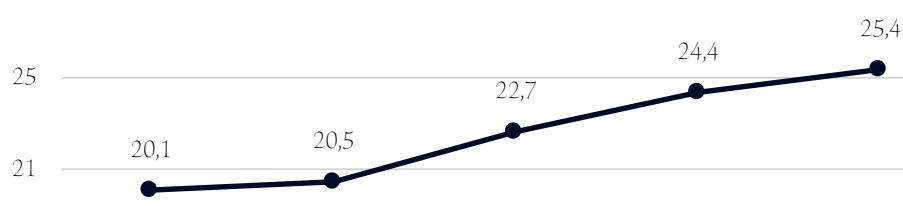

17

\begin{tabular}{llllll} 
& & 11,7 & 11,9 & 11,9 & 12,7 \\
\cline { 3 - 5 } & 2011 & 2012 & 2013 & 2014 & 2015
\end{tabular}

$\longrightarrow$ Polska

$\longrightarrow$ UE -28

Żródło: Opracowanie własne na podstawie GUS (2015a-2016a).

Wykres 4.

Przyrost mocy osiągalnych rok do roku elektrowni ogólem wykorzystujących energię z OZE w Polsce w latach 2010-2017 według stanu na 30.06.2017 r. (w MW)

1800

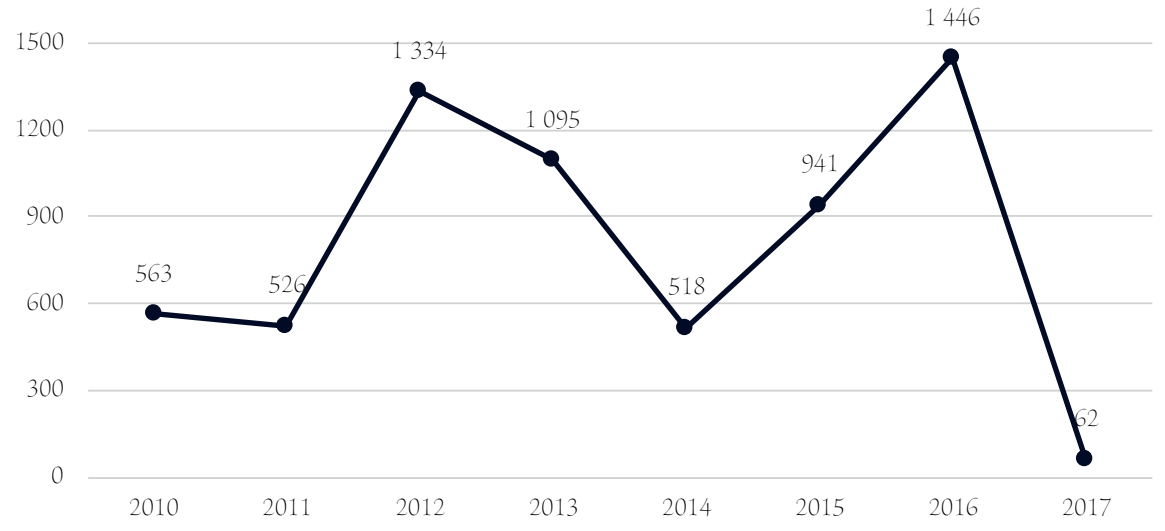

Uwagi:

Zakres czasowy poszerzono ze względu na dostępność danych.

Źródło: Opracowanie własne na podstawie URE (2017). 
Wykres 5 .

Wskaźnik zależności importowej Polski w latach 2010-2015 (w \%)

35

33

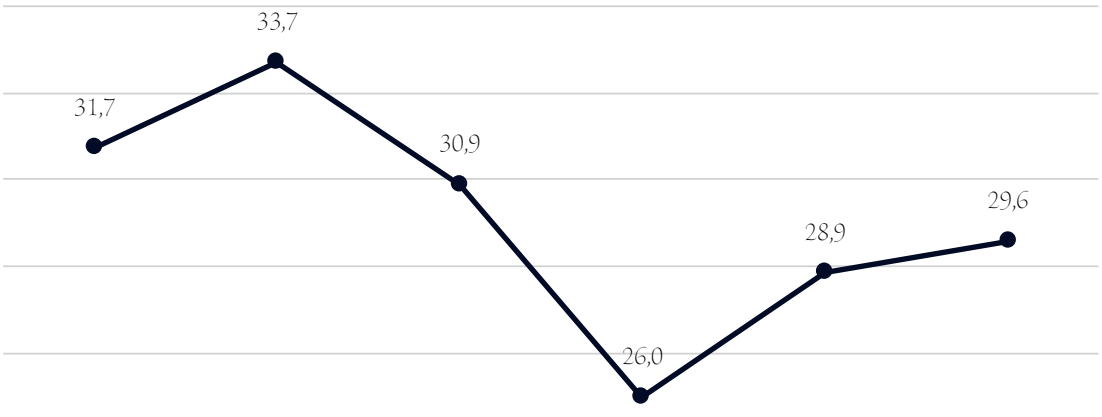

25

23

$\begin{array}{lllll}2010 & 2011 & 2012 & 2013 & 2014\end{array}$

Żródło: Opracowanie wlasne na podstawie GUS (2011b-2016b).

Wykres 6.

Wskaźnik intensywności energetycznej dla Polski i UE-28 w latach 2010-2015

320

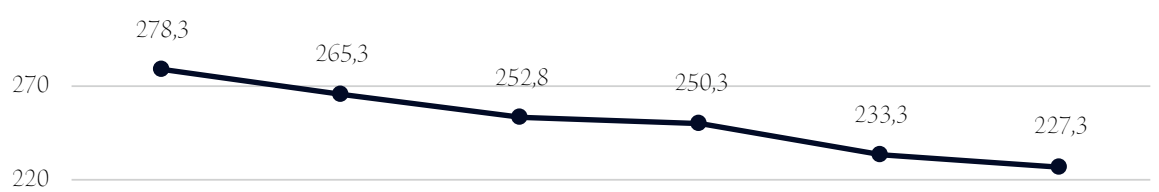

170

$$
137,5
$$

130,2

129,8

128,0

121,3

120,0

120

70

$2010 \quad 2011 \quad 2012$

2013

2014

2015

Źródło: Opracowanie własne na podstawie Eurostat (2017). 
Poland's energy security in 2010-2015: economic aspects

\begin{abstract}
Motivation: The issue of energy is a problem that systematically returns to political de-bate. At present, in the public opinion, there is a lack of consensus on an optimum energy production structure that would provide Poland energy security. The desire to show the relationship between the current situation of the Polish power industry and Poland's energy security was the main motive for choosing the subject of this paper.

Aim: The aim of this paper is to show the relationship between the use of conventional and renewable energy sources and Poland's energy security in the context of economic aspects.

Results: The analysis showed a low level of diversification of energy sources. It has been shown excessive dependence on import from Russia, significant energy intensity of the economy and unfounded, excessive support for the mining industry. On the basis of the conducted analysis, however, it is also possible to observe a gradual improvement of Poland's situation in these issues.
\end{abstract}

Keywords: energy security; conventional energy sources; renewable energy sources; energetics JEL: Q40; Q42; Q43; Q 48 